\title{
The interrelationship between politics and the military in
}

war

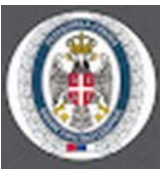

Received: 08/09/2021

Revised: 22/09/2021

Accepted: 02/10/2021

Published: 06/12/2021

Corresponding author: Momčilo Sakan

\section{Correspondence email:} momcilosakan@gmail.com

DOI:

10.5937/vojdelo2103021S

\begin{tabular}{|l|l|l|l|}
\hline c & e & o & n \\
\hline c & e & e & s \\
\hline
\end{tabular}

\author{
Momčilo Sakan \\ Nezavisni univerzitet, Banja Luka, Bosna i Hercegovina
}

\begin{abstract}
:
The problem of the interrelationship between the political and military elite is very complex, multidimensional, multi-hierarchical and relatively protected from the scientific and professional public and, as such, more difficult to understand. It is particularly relevant in war, where ties are looser and where the self-initiative of individuals and social groups comes to full expression, which is precisely the subject of this analysis. However, the subject is not considered in its totality, but is limited only to the territory of the former Socialist Federal Republic of Yugoslavia (SFRY) in the period from the 1980 s onwards. The events out of that time were used as an empirical basis for illustrating and arguing one's own views. The subject of this paper is structured in five separate parts. In the first part, the epistemological and logic bases of the relationship between politics and the military in war are presented, with the focus on the noticed weaknesses in the theoretical and normative sphere and their consequences for real practice. In the second part, a comparative analysis of the goals of politics and the military has been done, with an emphasis on the necessary need for them to coincide at the state level and be conducted by joint efforts. The third part explains the relationship between the military and politics at the most general level. It has been proven that politics is more general and that it directs the entire activities of the society including the deployment of the military in war. The fourth part presents the models of the relationship between the military and politics at strategic level. It has been unequivocally proven that politics is superior to the military, which does not exclude the possibility of intensive negotiations before making definite decisions on the deployment in combat operations. Finally, the fifth part explains the relationship between local government representatives and units at tactical level. The links between management and cooperation between these entities with the focus on communication difficulties and consequences are explained.
\end{abstract}

Keywords: the military; politics; interrelationship; war; goals; armed conflict

\section{INTRODUCTION}

In the field of social activity, there are numerous problems and the general condition and prosperity of states and nations depend on their complex research and successful solution. Among them the problems of multidisciplinary nature, i.e. those problems that do not appear in a "pure" form, do not cover only one field and do not have clearly defined connections and relationships, are particularly relevant. This is, inter alia, the problem of the interrelationship between politics and the military in general and in war in particular. It is at the junction between these two important activities, and representatives of politics and the military, as well as numerous other entities of the society, participate in its solution.

The problem of the interrelationship between the military and politics is much more topical in war than in peace. In peace, there is the established continuity of relations between the legislature, the executive and the judiciary and the constancy of these relations with the military as an institution. The interrelationships are more direct, the dynamics of the activity is less, the phenomena are more predictable, and the corrections are simpler. In war, it is much more complex and difficult to execute because many ties are broken and those relations that were established in peace are disturbed, and all weaknesses are paid with human lives. 
The problem has not been sufficiently researched. It is at the very top of the state policy and, as such, due to protection from the public, injury to the vanity of individuals and groups of people, and also due to the lack of courage and intellectual honesty, is not interesting for most theorists, who are inclined to impartial and objective research. This is also influenced by the occasional nature of armed conflicts, which indicate the fact that the mentioned problem is not interesting in peace for many scientists. It is not so relevant for research, even when it really happens in some other, distant country. It becomes relevant only when it occurs in its own state and happens to its own people, and then it is too late for complex research.

The complexity of the problem is reflected in the fact that it covers a wide area of almost all sciences and scientific disciplines. Numerous entities that belong to different institutions, political orientations, with different economic and political interests and different political, military and other power at national and international level participate in the process of its solution, but that is not the subject of this analysis. The subject of the research primarily refers to the interrelationship between political and military elites in power in wartime conditions and is mainly limited to the territories of ex-Yugoslavia since the 1990s. The events out of that time are mostly used as an empirical basis or argumentation of one's own views.

The research of the mentioned subject started from the well-founded hypothesis that the main preconditions for the successful functioning of the interrelationship between politics and the military in war are good epistemological and logic foundations set in peace, proper definition of goals and competencies of entities at general and local level. Other elaborate hypotheses are defined symmetrically by subheadings in the text.

The research has used almost all scientific methods with the focus on content analysis, comparative historical method, test method and logic methods that have been present in the entire process of analysis of the collected material and the development of this document.

\section{EPISTEMOLOGICAL-LOGIC AND METHODOLOGICAL BASES OF THE RELATIONSHIP BETWEEN POLITICS AND THE MILITARY IN WAR}

In our military science, as well as in other sciences in the society, for many years, general theoretical issues related to political and military activities in war have rarely been addressed. It is not just about the relations between the subjects of those two types of activity, but, above all, about a more extensive problem that covers the entire area of activity of the state and its institutions in war - from philosophical and methodological approach to theoretical elaboration of specific activities.

In the SFRY, there were attempts to research and theoretically shape this problem. The results, however, remained below expectations due to a unilateral approach and an attempt to reduce the problem to the field of military doctrine and to offer ready-made solutions for the country's defence. The consequences of such a methodological orientation were multiple. Firstly, the national defence doctrine did not cover the problems of war in totality, but only a dimension of it - the national defensive war. Secondly, ready-made solutions were offered, which is impossible. Thirdly, such an approach directly affected the unilateral education of officers. Instead of a consistent and well-argued theory of war, they studied doctrinal and normative documents without a complex approach and sufficient empirical and logic basis. Fourthly, the conditions under which the main premise of the doctrine of the national defensive war was derived, were not controlled. The premise that the whole country is in the form of "the hedgehog with twenty-two million spines" and that the entire nation will "stand up" in the defence of its integrity was appropriate for the 1970s, but in the 1980 s it became unsustainable. Fifthly, the entire process of preparing and conducting actions in war is politicized. Political terms, complex syntagms and empty phrases such as working people and citizens, basic organizations of associated labour and the like have marked their entrance into military terminology. Sixthly, due to the bias and false patriotism of its authors, the opponent was neglected, that is, war was considered as a 
unilateral category. Seventhly, the creators of such a doctrine neglected the lowranking officers in the military. And eighthly, with the attitude that "the right and obligation of all working people and citizens is to defend their country", the obligations and competencies of the subjects in war have been intertwined. This was clearly evident in the 1990 s wars, when, instead of professional officers, the command of units was sometimes taken over by local politicians and party leaders.

Defining the general theoretical models of politics and the military in general and in war in particular is also a great difficulty. The general policy model implies the practical activity of the government that is directed towards the general interests of the state and people. However, other variants are possible, for example, that politics favours the class, party and other interests and subordinates all activities of the state institutions including the military ones to those interests ${ }^{2}$.

The situation is similar to the state in the military. In a multi-party system, the military is expected to be highly professional and depoliticized, and also brave in the fight for general state interests. In reality, however, this is not always the case. The most common cases of deformation are when individuals in the top brass and a part of the staff in hierarchy, due to subservience, the lack of knowledge for the function they perform, the aspiration for faster advancement, the fear of responsibility and other motives, neglect general state interests and unreservedly put aside groups of people or deformed parties in power ${ }^{3}$. As a rule, the more closed the society is, with less democracy, the greater the possibility of anomalies is.

There are also difficulties of methodological, logic and semantic nature. This particularly relates to participants in relationships and the ways in which those relationships can be viewed. In the epistemological sense, these are relations between sciences, specifically between political and military sciences. In the practical and logic sense, these relations can be viewed in general - between the subjects of politics and the military, then specifically - between the political elite in power and the General Staff and individually - between individual representatives of politics and the military.

Semantic difficulties are particularly present when choosing the terms for the representatives of politics and the military. The political power holders in a society are known and defined by the constitution. In order to solve problems more efficiently, in a state of war, the parliament and the government, in most cases, transfer a part of their competencies to a person or a group of people. A person who has that political power in specific situations also has certain semantic meaning. The most common names are: king, emperor and president, for which the common term is most often used: ruler, statesman, head of state, representative of politics and the like. The situation is similar with military representative. Historically, he can be in the capacity of military leader, Commander-in-Chief, military commander, Chief of General Staff and the like.

The problem of the relationship between the representatives of politics and the military is both normative and practical. It is best when there is no significant difference between these two categories. The greater the difference is, the more problematic state of those relations is, and the greater consequences. Anomalies are usually normative. Thus, for example, according to the constitutional solutions in the SFRY, there was the Presidency, as the collective Supreme Commander, and the Ceneral Staff of the Yugoslav People's Army, in the role of the Headquarters of the Supreme Command. However, when the war started, it was not known, that is, the general public did not know who a statesman was, and who the Commander-in-Chief was. The procedures in critical situations when, for example, that collective Supreme Commander cannot agree and make any decision were not defined, either. There was practically no direct connection between that collective Supreme Commander and the commanders of the armies that were directly subordinated to them. Some attempts were made through the General Staff, but it was only in the function of the Headquarters of the Supreme Command. The direct consequences of such a situation are well known - from defining impossible goals and attempts to introduce the political party in the Yugoslav People's Army to interfering in professional competencies. This can be seen in particular through the "go - stop" tactics and other military 
activities directed by politicians. Therefore, in the normative sense, it was not decided who represents the military, and who politics.

The problem of decision-makers is also present, especially in situations when not all state authorities can function normally. Usually, in these conditions, competencies and authorities are transferred to individuals - decision-makers. They are most often called a ruler (statesman) in the country, but it is more precise to call them decisionmakers at national and international level. However, in wartime conditions, they should have special powers, which need to be defined by the law and constitution.

Decision-makers can be classified according to different criteria, and the main ones are the way of decision-making and the persons participating in the decision-making process. There are formal and actual decision-makers in relation to the way decisions are made. Formal decision-makers, in accordance with the constitution and laws, make appropriate decisions and formally and legally sign some acts and decisions. Actual decision-makers are those on whose will the existence and content of the decision depends, which is formally announced after their consent. They are usually not known to the general public, and may be in the country or abroad. They can sometimes work against the interests of the state, which is very dangerous for the engagement of the military.

The other characteristic case is when a certain person (or institution) of a lower rank imposes himself with his charisma and takes on the role of a formal (and/or actual) decision-maker. Thus, for example, the role of formal decision-makers in the SFRY was taken over by the presidents of the Republics at that time, and the members of the Presidency of the SFRY took over the role of transmitters and, eventually, interpreters of the decisions which they were not allowed to vote against. Such cases were also present later. Thus, for example, the President of Serbia Slobodan Milošević had greater power and authority than the presidents of the FR Yugoslavia at that time - the Supreme Commander of the Armed Forces, which had very negative consequences for the military as a whole, from the choice of war goals to relations at state, regional and local level ${ }^{4}$.

\section{THE RELATIONSHIP BETWEEN THE GOALS OF POLITICS AND THE MILITARY IN WAR}

In general, the goals of politics and the military in war are completely different. The goal of politics is peace. This does not mean any kind of peace, but better and more just for all parties to conflict. If unjust peace is concluded, new war is more likely to break out because the aggrieved party will always try to improve such a humiliating relationship, in which it was brought by unjust peace.

Politics fulfills this goal by coordinating the efforts of the entire potential of the society including the effects of military action in war. What it loses in military field, politics compensates by skillful diploma$\mathrm{cy}$, and thus by continuously harmonizing the efforts of forces in military, diplomatic, economic, ethical and other spheres, it opposes and harmonizes its main positions with the enemy and concludes peace. At the same time, it is very important to avoid two unfavourable extremes in which politics can be brought. The first is not to exhaust your strength and potential in war to the point of complete exhaustion and, in that way, ruin the future of your people, and even your own. "Self-exhaustion in war", as Liddell Hart points out, "has destroyed more states than any external attacker" [1]. The other extreme refers to blindly following the successful actions of the military on the battlefield - without thinking about the later effects.

The goal of politics is, therefore, peace, not war. Therefore, in the theory of force, the rule is that the best policy is the one that does not introduce its country into war. Real politics will do everything to make war never happen. In war, human lives are lost, as the greatest value, and the achieved level of economic and other development of the society is destroyed. However, it would be very wrong to explicitly attribute the outbreak of war to the shortcomings of this or that government. Two or more opposing countries, political, national and other groups, take part in war, so the problem of peace or 
war is common. War is, thus, a consequence of the blockade of dialogue at negotiating table, but, regardless of that, it always ends at negotiating table.

Unlike politics, the goal of the military is to defeat the opponents in war, primarily by the armed means - combat operations. It subordinates all activities to such a goal, from manning and training, through organizational and formation solutions to conducting combat operations and achieving the set goal. The military, therefore, recognizes only two sides in conflict - its own and the enemy.

The goals of politics and the military also differ in terms of competence in definition. Politics defines a global goal in war, and also partial goals, for example, to the military, diplomacy, etc. The military, therefore, does not set goals for itself in war, but only sets goals in some combat actions - battles and operations.

The mentioned generalization of goals refers to the so-called "pure" situations. Things, however, are not that simple. Each rule has its exceptions, and in practice a number of subvariants may appear. It is not uncommon for generals to turn into peacekeepers and try to restrain their belligerent politicians especially in the phase of analyzing the possibility of engaging the military and achieving some goals. When the decision is made, if general does not resign, things are put into place again - generals try to defeat the opponent, and politicians talk about peace 5 .

The experiences from our recent history, however, show that there are numerous examples when the goals of engaging the military have not been properly set. At the beginning of the civil war in the territory of the SFRY, for example, someone set an impossible goal for the Yugoslav People's Army. The military was ordered to go out in the field to separate the warring parties; namely, to go to war with full war equipment, without defining who its enemy was. The practice has shown that this goal could not be achieved. The military was in the sandwich between two parties and, as such, did not suit either conflicting side. Some accused it of being inactive, while others accused it of being hostile and occupying.

Unfortunately, it turned out that the Serbian political elite was very unprepared for the changes that affected Europe and the SFRY ${ }^{6}$. For more than ten years of rule, the political elite, embodied in the regime of Slobodan Milošević, was very vague and confusing. It is certain that in the beginning it defended the multinational federation until its dissolution. There are opinions that the regime advocated for the Serbs to remain in a single state, but that was never made public. However, the fact is that the defence of the Serbs in Krajina was not the state project of Serbia at that time?

The political elite of Milošević then reduced the Serbian state territory to the borders of two federal units of the FRY (Serbia and Montenegro), which, at the very beginning, as a single national territory, was called into question. Such a policy had a very confusing and disorienting effect on officers, especially on those individuals who were born outside the borders of the Republic of Serbia. It became clear only at the time of the NATO aggression on the FR Yugoslavia, when the government declared a state of war and unreservedly decided to defend the country. The national unity was also achieved. Ordinary people literally defended the bridges on the Sava and Danube with their bodies, which lasted until different party flags and other symbols began to appear in the mass of those people.

The new "democratic" government, from October 5, 2000, promised in its election campaign what proved to be impossible. When it won, it unreservedly directed the geopolitical code of Serbia towards Euro-Atlantic integration, expecting that the US, NATO and European Union would open their doors wide, that the EU funds would come to Serbia by themselves and that the standard of employees would grow by arithmetic progression. The result of all of this, with honourable exceptions, was the following: a subservient attitude towards the Western powers; withdrawal of the charge against the NATO countries that carried out the aggression against the FRY; self-blame and apology; further destruction of the economic system of Serbia; collapse and wild privatization of profitable companies; 
disbanding the military; lack of care for fighters who defended their country; increase in the number of unemployed; increase in the number of unresolved court disputes; rising corruption and crime; favouring party over state interests; nepotism and employment of unprofessional party personnel; shameless enrichment of individuals and social groups; general disagreement and struggle over competencies and privileges; inter-party competition and accusations...

It is evident that in the last few years visible results have been achieved in all fields. Numerous highways and railways have been built. Visible results have also been achieved in terms of gasification, improvement of the quality of central heating in many cities, construction of hospitals, schools, kindergartens, parks, protection of pregnant women and babies. Huge efforts have been made to modernize and equip the Armed Forces and to improve the quality and quantity structure of its personnel. All this, in a way, points to the fact that better times are coming.

\section{POLITICS AND THE MILITARY AS GENERAL AND SPECIAL}

Politics and the military, in the logic sense of the word, are treated as general and special. Politics is much more general than the military. It, together with other subjects, defines the national interest and the geopolitical code of the state. It deals with many problems including the problems of war in totality with political, economic, military, diplomatic, religious and other dimensions. In contrast, the military deals with only one dimension of war - active participation in armed conflicts. Politics is, therefore, more general because it studies war in totality as a very complex phenomenon and deals with the problems of defence and prosperity of the people and the state in general.

Politics significantly influences the military by creating favourable economic, diplomatic, moral and other conditions for conducting combat operations. It occurs as the main factor in determining the size and composition of the military, its place in the country and reputation by people, the quality of officers, the impact on life standard and quality in general, the design and adoption of new weapons, data collection on a wider scale, the use of psychological and propaganda actions and other means that will enable faster and more efficient achievement of the set goal in war. At the same time, it bears the consequences of a possible defeat in war. Therefore, for a scientific explanation of each war, it is necessary to consider the policy that preceded it, which was conducted in its course and which continues after it.

The activities of politics and the military in war are also directly connected. At their highest point of view, especially in war, they are significantly closer. This does not mean that the work of waging war should be left to professional officers who would judge from a purely military point of view. On the contrary, the main lines of war are defined by political, not military power. It goes without saying that it does so with strict respect for military sciences and capabilities of the military. This, further, points to the conclusion that political representatives have to be well acquainted with armed conflicts, and not only from a purely military, but, above all, from a political point of view? .

\section{THE RELATIONSHIP BETWEEN POLITICS AND THE MILITARY AT STRATEGIC LEVEL}

The relationship between politics and the military at strategic level, historically, has been very different. There were periods when opinions prevailed that strategy was older than politics, that they were equal or that politics was above strategy.

The opinion that the military is older than politics was more present in earlier times, but it remained in some countries even later. There are numerous examples of Caesarism or Bonapartism, when strategy in the hands of skilled commanders emerges from its subordinate role and is imposed on the state policy. The examples of such theoretical understanding and practical action are related to many countries, but they are typical of the Prussian, and later the German Armed Forces and the state. Thus, for example, Moltke the Elder (Helmuth Karl Bernhard von Moltke), misinterpreting Clausewitz (Colmar 
von der Goltz), set the formula politics - war - politics. He believed that politics in war was indisputably within the competence of soldiers, and that politics after war passes again into the competence of politicians. Such a view was advocated by von der Goltz, who simply ruled out wartime politics [2]. He advocated the position that politics should be silent as soon as cannons thunder. Similar to him, Ludendorff (Erich Friedrich Wilhelm Ludendorff) in his book "Warfare and Politics" points out that war is foreign policy by other means and that all politics has to serve war [3]. Such militaristic views came to the fore during World War II in the Third Reich, when Hitler (Adolf Hitler) proclaimed himself the commander of the army, who personally, but obviously unprofessionally, led the land operations. This was particularly evident when he took command of the army in front of Moscow and usurped control over the operations. Then his conflict with generals followed, and ultimately, his total defeat.

The superiority of strategy to politics is still a common phenomenon today. It is most often the matter of the usurpation of power by the top brass, i.e. a junta. The rule of the armed force (militarism or military dictatorship) has never brought better future to a nation. It can be tolerated only as a temporary solution until the election of a new civilian government that will lead the entire politics of the country.

Proponents of the opinion that strategy and policy should be equal believe that this is the simplest and fastest way to solve problems of economic and other nature because all functions (military, political, economic, etc.) are concentrated in one person. Such an opinion is also irrelevant. The fact that both of these functions are integrated in one person does not mean much because combat actions will be directly commanded by professional officers, and politics will be led by politicians. Otherwise, it could happen that statesmen cross the boundaries of their competence and obstruct their military bodies, and military bodies "set the wrong requirements according to which politics should be subordinated to their leadership" [1].

The opinion that politics is older than strategy was, and still is, advocated by the greatest number of military theorists ${ }^{10}$, and it is dominant in almost all countries of the world. Politics is, therefore, the "reflector" that illuminates the way for the military (and people) and points in the directions that lead to faster and more efficient prosperity and progress of people and through which the society can move most successfully". A typical example of such a relationship is the Allies in World War II. In the West, for example, decisions from the great strategy, i.e. war policy, were made by statesmen. Generals led operations and were subordinate to the statesmen who appointed and replaced them ${ }^{12}$.

These three typical examples are rare in practice. The combinations of relationships are much more common - even during a war. There are frequent situations when politics is initially illegally interfered in the responsibilities of generals, and later things are put in their place, but reverse cases have also been recorded.

A typical example of political interference in the jurisdiction of strategy refers to the initial phase of the American Civil War (1861-1865) when in the Nordic States the Congress, through its Military Committee, interfered excessively in the responsibilities of generals and demanded that actions be taken on the battlefield without the commander's consent. The balance between strategy and politics was not achieved until the later phase of the war, when President Lincoln (Abraham Lincoln), after a lot of hesitation, took the war into his hands and left the conduct of operations to General Grant (Ulysses Simpson Grant) [3].

The opposite example, when politics was subordinated to the military at the beginning of the war, refers to France in World War I, when President Poyincaré (Raymond Poincare) gave his Commanderin-Chief, Joseph Jacques Cesaie Joffre, complete freedom of action. He wrote in his diary: "The army has the floor now. I am silent and I obey." The direct consequence of such a situation is insufficient information and numerous problems that only politics can solve. Joffre also hid his intentions and operations in preparation from the Government. Only later did he agree to attack the Dardanelles and 
support Serbia. In the second period of the war, President Clemenceau took over the war. He confirmed this with the famous saying: "War is too important thing to be left to generals" [3].

The superiority of politics in theoretical terms is directly reflected in the practical relations between the subjects. The commander is directly subordinate to the statesman and is loyal to him. He avoids conflicts with him because it has a negative effect on the state of the military and people. He wisely and rationally engages the forces assigned to him by politics to achieve some goal in combat operations. If he assesses that these forces are insufficient for him, that the set goal is unrealistic or that the demands of the statesmen are unattainable, he has the right to point that out and to demand appropriate corrections. If this is not accepted, he can refuse further command and resign ${ }^{13}$. On the other hand, the statesman assigns goals to the military, which he defines on the basis of the knowledge of military sciences, adopted doctrine and full respect for the state and capabilities of the military and people. He does not interfere in the competence and professional affairs of the commander regarding the direct deployment of forces to combat operations and does not interfere with his command. However, he constantly adapts to conditions and has the right, in accordance with new situation, to change goals, and if necessary, to change the commander and other commanders who he has lost confidence in.

In addition to the general theoretical model of the statesman-commander relationship, numerous other extreme cases and conflicts have been recorded in practice - from the most ordinary intolerance, through mutual arbitrariness and disrespect and the creation of the so-called status quo, to riots and open armed actions. In these conflicts, the statesman usually seeks support from the government and the assembly, and the commander from subordinate generals and the army.

\section{RELATIONS BETWEEN LOCAL GOVERNMENT REPRESENTATIVES AND UNITS AT TACTICAL LEVEL}

The problem of the relationship between local government representatives and unit commanders at tactical (and operational) level, although very relevant, has not been sufficiently researched in the theory of the combat.

By the nature of things, these relations should be stronger and more direct, not only because of a great number of tasks that have to be conducted, but also because of the reality of situation and direct possible danger to people and material resources. The tasks in question are numerous and complex - from mobilization and execution of military, work and material obligations of citizens, through the arrangement of zone and conduct of a great number of tasks in the field of combat operations, to regulating the issue of population evacuation and potential evacuation of material goods. All this is solved practically in the field, most often in conditions of imminent danger to people and material goods.

Many problems can arise at that level of command, and the main ones are: poor functioning or severance of ties at strategic level, then on the military subordination line, on the line of political subordination and mutually on the line of local government - unit command. The disruption of good relations at local level can also be a consequence of arbitrariness and disrespect between representatives of local authorities and military commands. Most often, local authorities, by inertia, starting from the views on the superiority of politics at the highest level, and often out of arbitrariness, exceed their authority and try to subordinate military commands. In that sense, they take over a part of the competencies of military commands, and even more than that. In extreme situations, there have been cases of local authorities appointing, discharging and physically removing military commanders, then creating an army according to their (usually party) model and using it exclusively for their needs - without respecting military subordination. On the other hand, the disturbance of relations at local level can also be a consequence of arbitrariness and exceeding the authority of representatives of local commands. Using the power of weapons and other "arguments", and under the guise of the need for a unified ac- 
tion, they try to put all activities under their control. This unprofessional takeover can lead to relationship breakdown, intolerance, collision and more serious conflicts.

Overcoming the mentioned disorders implies the consistent implementation of the relationship of direct cooperation, respect, tolerance and non-interference in professional competencies. Local politics takes care of the functioning of all activities in its territory. Moreover, it also closely monitors and supports military activities and solves all related problems in direct cooperation with military commands. On the other hand, the commander adjusts his requests to unit needs, but in accordance with general situation in the territory and the capabilities of local government. The problems that the representatives of local government and the military cannot solve through direct cooperation are solved through higher institutions - by the subordination line.

\section{CONCLUSION}

It can be concluded that politics and the military in war are directly and closely connected by many ties of different directions, intensity and levels of generality. In addition to closeness, there are also differences that are clearly evident in goals, generality and subordination. The goal that is defined by the military is usually victory in combat, while the goal of politics is peace, and not just any kind, but just peace for all parties to conflict. Politics is more general than the military. It prepares and wages war, as a very complex and multidimensional phenomenon, and the military combat actions - battles and operations. War plan is not made by the military, but by politics. The military draws up a plan of offensive or defensive combat operations, depending on the requirements of politics. Hence, the military is not responsible for war, but for fighting, and in war it is subordinated to politics.

In principle, politics avoids war as a very unfavourable means of solving problems. However, if it decides for such a war, it energetically engages all necessary forces - military, diplomatic, economic, cultural and other, trying to solve those problems for its benefit as soon as possible. The activities of these forces are energetically directed from one place and measures are taken to rationally and efficiently exploit successes and neutralize failures of some of them. Thus, for example, successful combat operations provide diplomacy with favourable conditions for peace negotiations, which it successfully uses. However, if there is hesitation in combat, the situation is saved by skilful diplomacy that creates unexpected dangers for the enemy - by engaging some of the allies, gaining public opinion and key people in international organizations and associations, or in some other way. Each of these activities is preceded by mature assessment of situation and prediction of future events in order to assess the moment and intensity of action in the coming period. Otherwise, unrealistic estimates based, for example, on great initial successes in military field may lead to inadequate engagement of other forces, and vice versa.

\section{Endnotes}

'On the phenomenon of peace more in: Ilija Kajtez, Srđan Starčević, Bojana Ružičić, „The Essence of Phenomenon of Peace and the Notion of Peace Building", Vojno delo, 8/2018, pp. 5-23. [4]

${ }^{2}$ Noticing such a danger, E. R. Simpkin points out: „However, whatever the motives of their leaders were, the governments of the First and Second World in the nineteenth and twentieth century, in general, seemed to be ready to start war regardless of their capabilities and prospects and to continue it regardless of its outcome, apparently believing that the destruction of their country is more acceptable than their removal from power ". (Ričard, E. Simpkin: Nadmetanje u brzini manevra, O ratu u XXI veku, VINC, Beograd, 1991. p. 254) [5]

${ }^{3}, \ldots$ perhaps we can penetrate the secret of the particular difficulty of electing the military leaders ... the methods of the military management are such that those who dare to think for themselves are usually eliminated." Karl Poper: Otvoreno društvo i njegovi neprijatelji, 1. Čar Platona, Bigz, Beograd, 1993. p. 182. [6]

${ }^{4}$ It is very interesting that Presidents Slobodan Milošević and Franjo Tudjman, at the negotiations in Dayton, took over the role of negotiators instead of the representatives of the Serbian and Croatian people in Bosnia and Herzegovina. 
${ }^{5}$ Thus, for example, the NATO military commanders convinced their politicians of the futility and irrationality of carrying out the air strikes on the Serbs in Bosnia. When that failed, however, and when the decision was made, those peacekeeping commanders turned into energetic implementers in a very brutal way.

${ }^{6}$ "Serbs did not have a statesman with vision, politicians who understood the great changes that have taken place in the political being of the world and modern civilization." (Dobrica Ćosić: Razgovor nedelje - rušiće nas vreme i potomci, Politika, Beograd, October 2, 2005) [7]

${ }^{7}$ At first, it was lenient in supporting the maximalist policy of the Knin Serbs, and then it left them to the „homeland” crime of Tudjman's soldiers and expulsion from the centuries-old homes. (Dobrica Ćosić: Borimo se za preporod Srbije i sve radosti života, Interview in: Politika, May 31, 2011) [8]

${ }^{8}$ „Political struggle cannot become a matter of life and death at the expense of your and my children, family and nation. ... Politics cannot be the basis for getting rich, for changing the social status. On the contrary, whoever deals with politics, ... acquires wealth, ... must go to prison. Because it makes Serbia corrupt ... " (Tijanić o srpskim političarima, https://www.youtube.com/watch?v=6aiNOkrHsH8 (April 4, 2021) [9]

${ }^{9}, \ldots$ without certain knowledge of the art of war, there should be no political leadership." (Karl fon Klauzevic: O ratu, Grafičko preduzeće „Vuk Karadžić”, pogon združena štamparija, Beograd, 1951, p. 524) [10]

${ }^{10}$,Politics is the mother of war; it is the intelligence, and war is only an instrument, and not the other way round "..., „From this point of view, perfect plans are created, comprehension and judgement become easier, more natural, conviction stronger, motives more satisfying, and history more understandable." (Karl fon Klauzevic: O ratu, Grafičko preduzeće „Vuk Karadžić”, pogon združena štamparija, Beograd, 1951, p. 523.) [10]

",The conditions that war should arise from are determined by politics; Politics, so to speak, emphasizes war on the stage (mise en scene); it determines the strength of parties and the borders of the battlefield.”... „State policy in general, which does not take into account these basic assumptions, prepares sad disappointments for itself, and at the same time can bring disaster to the state itself." (Živojin Mišić: Strategija, VINC, Beograd, 1993, p. 8 and 9) [11].

${ }^{12}$ These relationships, most often, were not so uniform (stereotypes). Churchill, for example, sometimes considered complex problems in conducting operations, and even some tactical details. When it comes to practical execution, he leaves his general great freedom in preparing and conducting combat operations in the field. (Petar Tomac: Odnos politike i strategije, članak, Vojno delo br. 3/1953, Beograd, 1953, pp. 14-16) [12]

${ }^{13}$,General must never allow himself to be forced into battle, and must never give this up without great trouble. If he decides on it, he must be careful to save more human blood than to shed it." (Jovan Bl. Jovanović: Napoleon I, Beograd, 1925, p. 35) [13]

\section{REFERENCES}

1. $\quad$ von der Goltz C. Das Volk in Waffen. Berlin. 1890. [Google Scholar]

2. Kajtez I, Starčević S, Ružičić B. The essence of phenomenon of peace and the notion of peace building. Vojno delo. 2018;70(8):5-23. [SCIndeks] [PDF] [Google Scholar]

3. Andrejevič SA. Strategija. Beograd: Vojno delo. 1956. [Google Scholar]

4. Gliksman A. Govor rata - čemu prethodi Evropa 2004. Beograd: Vojnoizdavački i novinski centar. 1991. [Google Scholar]

5. ̌̌omini A. Pregled ratne veštine. Beograd: Prosveta. 1952. [Google Scholar]

6. Vojna nauka. Beograd: VIZ. 1971.

7. Ćosić D. Borimo se za preporod Srbije i sve radosti života, Intervju. Politika. 2011; Intervju, 31. 5. [Google Scholar]

8. Ćosić D. Razgovor nedelje - rušiće nas vreme i potomci. Politika, Beograd. 2005;2. 10. [Google Scholar]

9. Mišić Ž. Strategija. Beograd: VINC. 1993. [Google Scholar]

10. Rendulić Z. Ratovodstvo i naučno-tehnički progres. Beograd: VINC. 1992. [Google Scholar]

11. Jovanović JB. Napoleon I. Beograd. 1925. [Google Scholar]

12. Poper KR. Otvoreno društvo i njegovi neprijatelji - čar Platona. Beograd: Beogradski izdavačko-grafički zavod. 1993. [Google Scholar]

13. fon Klauzevic K. O ratu. Beograd: Grafičko preduzeće 'Vuk Karadžić'-pogon združena štamparija. 1951. [Google Scholar]

14. Hart L. Strategija posrednog prilaženja. Beograd: Redakcija vojnog dela. 1952. [Google Scholar] 
15. Vučinić M. Kako osigurati razvoj. Vojska. 1995. [Google Scholar]

16. Marković M. Etički problemi nauke. Gledišta. 1976. [Google Scholar]

17. Sakan M. Vojne nauke. Beograd: VIZ. 2003. [Google Scholar]

18. Sakan M. Geopolitika u savremenom svetu. Banja Luka: NUNB. 2012. [Google Scholar]

19. Sakan M. Metodologija vojnih nauka. Beograd: VIZ. 2006. [Google Scholar]

20. Sakan M. Nauka o međunarodnim odnosima. Banja Luka: NUNB. 2012. [Google Scholar]

21. Vujanović N. Uloga naučnoistraživačkog rada u procesu transformacije i izgradnje Vojske Jugoslavije. Novi glasnik, VINC, Beograd. 1993(4-5). [Google Scholar]

22. Tomac P. Odnos politike i strategije. Vojno delo, Beograd. 1953(3). [Google Scholar]

23. Tomac P. Predgovor. In: fon KlauzevicKarl, editor(s). O ratu. Beograd: Grafičko preduzeće 'Vuk Karadžić'pogon združena štamparija. 1951. [Google Scholar]

24. Simpkin RE. Nadmetanje u brzini manevra - o ratu u 21. veku. Beograd: Vojnoizdavački i novinski centar. 1991. [Google Scholar]

25. Cu VS. Veština ratovanja - rasprave o ratnoj veštini. Beograd: Vojnoizdavački i novinski centar. 1991. [Google Scholar]

26. Tijanić o srpskim političarima [Internet]. [cited (4. 4. 2021)]. Available from: https://www.youtube.com/wat$\mathrm{ch}$ ? $=6$ aiNOkrHsH8.

\section{Međuodnos politike i vojske u ratu}

\section{Sažetak:}

Problem međuodnosa političke i vojne elite veoma je složen, višedimenzionalan, višehijerarhičan i relativno zaštićen od naučne i stručne javnosti i, kao takav, teže saznatljiv. Naročito je aktuelan u ratu gde su veze labavije i gde samoinicijativa pojedinaca i društvenih grupa dolazi do punog izražaja, što je upravo predmet ove analize. Predmet se, međutim, ne razmatra u totalitetu već se ograničava samo na prostore nekadašnje Socijalističke Federativne Republike Jugoslavije (SFRJ) u periodu od osamdesetih godina dvadesetog veka pa nadalje. Događaji van tog vremena korišćeni su kao empirijska podloga i za ilustraciju i argumentaciju vlastitih stavova. Predmet ovog rada strukturiran je u pet posebnih delova. U prvom delu date su epistemološko-logičke osnove odnosa politike i vojske u ratu, sa težištem na uočenim slabostima u teorijskoj i normativnoj sferi i njihovim posledicama po realnu praksu. $U$ drugom delu izvršena je komparativna analiza ciljeva politike i vojske, sa težištem na nužnoj potrebi da se oni na državnom nivou podudaraju i zajedničkim snagama realizuju. U trećem delu objašnjen je odnos vojske i politike na najopštijem nivou. Dokazano je da je politika opštija i da usmerava celokupne aktivnosti društva, uključujući i angažovanje vojske u ratu. U četvrtom delu navedeni su modeli odnosa vojske i politike na strategijskom nivou. Nedvosmisleno je dokazano da je politika nadređena vojsci, što ne isključuje mogućnost intenzivnog dogovaranja i pregovaranja pre donošenja definitivnih odluka o angažovanju u borbenim dejstvima. I, na kraju, u petom delu su objašnjeni odnosi između predstavnika lokalne vlasti i jedinica na taktičkom nivou. Objašnjene su veze rukovođenja i saradnje između tih subjekata sa težištem na poteškoćama komunikacije i posledicama.

Ključne reči: vojska; politika; međuodnos; rat; ciljevi; oružani sukob 